\title{
Macrobenthos community structure of Kan Maw Island and adjacent areas of Myeik Archipelago, Myanmar
}

\begin{abstract}
A study of bimonthly variations in community structure of macrobenthos in the intertidal zone was carried out in Kan Maw Island and adjacent areas of Myeik Archipelago during the low tide duration. This research was conducted at eight stations around Kan Maw Island from May 2017 to February 2019. For each station, three replicates were taken with a quadrant $30 \times 30 \mathrm{~cm}$ (to a depth of $30 \mathrm{~cm}$ ) along a transect and sieved with a $1 \mathrm{~mm}$ mesh size. The macrobenthic biodiversity was represented by 73 species belonging to 42 families under eight major phyla viz. Mollusca (53.4\%), Arthropoda (20.6\%), Brachiopoda (1.4\%), Echinodermata (1.4\%), Annelida (19.2\%), Hemichordata (1.4\%), Coelenterata (1.4\%), and Nemertea $(1.4 \%)$. Three metrics were utilized to estimate diversity: Shannon-Weaver's diversity index $\left(H^{\prime}\right)$, evenness index $\left(E^{\prime}\right)$ and Margalef's richness $(D)$ using univariate analysis. The relationship of abundance and diversity indices (except richness, $D$ ) were positively correlated with sediment (silt and clay) but temperature, salinity and sand had a negative correlation during the study period. In addition, macrobenthic groups (except Mollusca, Arthropoda and Annelida) were significantly effected by salinity, temperature and pH, but not by sand (except Cnidaria), clay (except Annelida) and silt (except Cnidaria, Annelida, Mollusca, and Arthropoda).
\end{abstract}

Keywords: community, correlation, diversity index, macrobenthos, Kan Maw Island
Volume 9 Issue 4 - 2020

Moe Lwin Lwin, 'Yin Yin Htay, ${ }^{2}$ Zin Mar Aye,' Tin Tin Kyu, ${ }^{3}$ Chaw Su Lwin, ${ }^{3}$ Khin Khin San' 'Department of Marine Science, Sittwe University, Myanmar ${ }^{2}$ Department of Marine Science, Myeik University, Myanmar ${ }^{3}$ Department of Marine Science, Myeik University, Myanmar

Correspondence: Moe Lwin Lwin, Lecturer, Department of Marine Science, Sittwe University, Myanmar Emailmoelwimyk@gmail.com

Received: July 29, 2020 | Published: August 27, 2020

\section{Introduction}

The community of organisms that live on or in the bottom of a water body is known as "benthos". Over $95 \%$ of the known marine species are considered benthic. ${ }^{1}$ Benthic faunal communities are important components $^{2}$ in the intertidal zones as the presence or absence of benthic communities ${ }^{1,3}$ provide valuable information about a marine ecosystem's health over time. ${ }^{4}$ Macro-invertebrate organisms form an integral part of aquatic environment. They maintain various levels of interaction between the community and environment. ${ }^{5}$ Moreover, abundance and diversity of macrobenthic animal community might be good indicators ${ }^{6}$ to assess aquatic environmental pollution. The production potential of demersal fishery of the near-shore region is dependent on the production of benthos of the region.?
In Myanmar, the Myeik Archipelago is composed of over 800 islands in the Tanintharyi coastal region. Among them, the present areas are located between the Morrison Bay and Whale Bay at the edge of KyunSu Township. Kan Maw Island is a central island that is abounded with the water. Its adjacent areas are interconnected with the mainland. People who lived in these areas eat some mollusk groups and some crustaceans and also export to Thailand. Macrobenthos can support people as a food, bait and provide income. The objectives of the present study are: 1) to investigate macrobenthos in the intertidal zone, and 2) to compare the macrobenthos community structures of different stations located in Kan Maw I and adjacent areas (Table 1).

Table I Variation and deviation of mean temperature, salinity, $\mathrm{pH}$ with abundance at eight stations

\begin{tabular}{lllllll}
\hline Sr. no & Stations & No. of species & Mean abundance & Mean pH & Mean salinity & Mean temperature \\
\hline 1 & Kan Maw & 26 & $305 \pm 14.7$ & $6.1 \pm 0.2$ & $31 \pm 3.18$ & $30 \pm 2.2$ \\
2 & Taw Kar & 18 & $148 \pm 7.8$ & $6.0 \pm 0.2$ & $30 \pm 2.88$ & $29 \pm 1.8$ \\
3 & Maw Khaung Tone & 29 & $248 \pm 11.2$ & $6.0 \pm 0.1$ & $26 \pm .09$ & $27 \pm 3.4$ \\
4 & Ka Lein Bae & 21 & $235 \pm 13.5$ & $6.0 \pm 0.1$ & $25 \pm 5.19$ & $28 \pm 3.0$ \\
5 & Oak Pho Maw & 45 & $489 \pm 16.7$ & $6.2 \pm 0.2$ & $31 \pm 3.87$ & $29 \pm 1.3$ \\
6 & SandarNge & 18 & $152 \pm 6.3$ & $6.1 \pm .1$ & $26 \pm 4.89$ & $28 \pm 1.0$ \\
7 & KyaukPeit & 16 & $143 \pm 10.4$ & $6.1 \pm 0.2$ & $30 \pm 3.37$ & $29 \pm 1.8$ \\
8 & Chaung Nyi Ko & 20 & $66 \pm 2.6$ & $6.1 \pm 0.2$ & $26 \pm 5.76$ & $28 \pm 1.4$ \\
\hline
\end{tabular}




\section{Materials and methods}

\section{Study sites and taxonomic studies}

Macrobenthos samples were collected bimonthly from the intertidal zone of eight stations: Kan Maw (Lat. 11 ${ }^{\circ} 48^{\prime}$ 6.236" N,

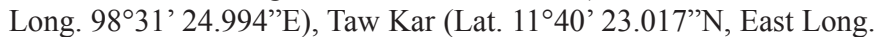

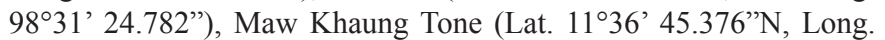

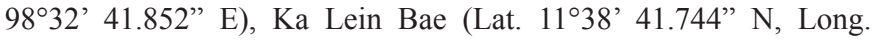

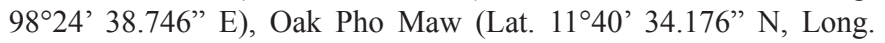

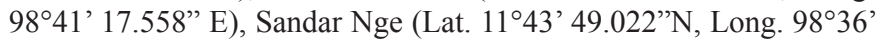

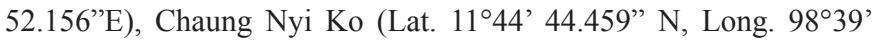

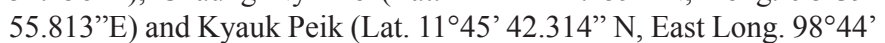
2.438”) during May 2017- April 2019. The shore was divided into three levels: the high-tide, mid-tide and low-tide levels. Quadrats were randomly placed along a line transect perpendicular to the shore. In each station, 3 replicates were taken with a quadrat of $30 \times 30 \mathrm{~cm}$ (to a depth of $30 \mathrm{~cm}$ ) at random intervals along the transect. The samples were sieved through a $1 \mathrm{~mm}$ sieve and the retained materials were preserved in $4-7 \%$ seawater formaldehyde solution for further analysis and taken to the laboratory. In the laboratory, samples were rinsed with fresh water, sorted according to taxonomic forms under hand lens, binocular microscope and compound microscope. After 10 days these specimens were transferred to $70 \%$ alcohol for storing. Water temperature, salinity and soil $\mathrm{pH}$ were measured by thermometer; refractometer and soil $\mathrm{pH}$ tester respectively. Abundance of macrobenthic fauna was calculated as number of individuals per $\mathrm{m}^{2}$.Sediments were transferred to measuring cylinder and settled for one week. Sediment texture was analyzed by precipitation methods and plotting in triangular diagram that based on the nomenclature of sediment to estimates and, silt and clay components. Identification of samples were classified down into genus and species level based on. . $^{81}$

\section{Data analysis}

Several diversity indices were used to describe the data.

For the Shannon-Wiener Index $\left(H^{\prime}\right)$, species diversity is calculated according to ${ }^{22}$ formula,

$$
H^{\prime}=-\sum_{\mathrm{i}=1}^{\mathrm{S}} P i \operatorname{Ln} P i
$$

where,

$P i=\mathrm{ni} / \mathrm{N}=$ Proportion of individuals of the total sample of the $\mathrm{i}^{\text {th }}$ species.

$\mathrm{N}=$ Individual number of all the species in total,

$\mathrm{ni}=$ Individuals number of the $\mathrm{i}^{\text {th }}$ species, and

$\mathrm{S}=$ Number of species

According to ${ }^{23}$, Equitability ( $\left.E^{\prime}\right)$ was measured by using the following formula,

$$
E^{\prime}=\frac{H^{\prime}}{\log \mathrm{S}}
$$

Here,

$\mathrm{S}=$ Species number in a population

\section{$H^{\prime}=$ Shannon-Wiener Index}

The Margalef 's Index (Species richness, D) was calculated according to ${ }^{24}$,

$$
D=\frac{\mathrm{S}-1}{\operatorname{Ln} \mathrm{N}}
$$

Here,

$\mathrm{N}=$ Individuals number in total of sample

$\mathrm{S}=$ Species number in sample

$\ln =$ Normal $\log$

Multivariate methods use classification and ordination methods to compare communities on the basis of the identity of the component species and relative importance in terms of abundance. To make comparisons between the stations, similarity coefficients were calculated by using Chord distance (CRD) index formula. ${ }^{25}$ The calculation is based on number of species and species wise quantity.

$$
\mathrm{CRD}_{\mathrm{jk}}=\sqrt{2\left(1-\mathrm{c} \cos \mathrm{jk}_{\mathrm{k}}\right)}
$$

Where the Chord Cosine (CCOS) is computed from

$$
\operatorname{CCOS}_{j k}=\frac{\sum\left(X_{j} X_{k}\right)}{\sqrt{\sum X_{j}^{2} \sum X_{k}^{2}}}
$$

Here,

$\mathrm{X}_{\mathrm{ij}}=$ The abundance of the ${ }_{\mathrm{i}}^{\text {th }}$ species in the $\mathrm{j}^{\text {th }} \mathrm{SU}$

$\mathrm{X}_{\mathrm{ik}}=$ The abundance of the ${ }_{\mathrm{i}}^{\text {th }}$ species in the $\mathrm{k}^{\text {th }} \mathrm{SU}$

Spearman's rank correlation

Spearman rank correlation coefficients were calculated between each pair of values of abiotic (salinity, temperature, soil $\mathrm{pH}$, sediment characteristics) and biotic (macrobenthos) variables. The correlation index is also referred to as Spearman's,

$$
p=1-\frac{6 \sum d^{2}}{n^{3}-n}
$$

Where;

$\mathrm{p}=$ Spearman rank correlation

$\mathrm{d}=$ rank of $\mathrm{Xi}$ - rank of $\mathrm{Yi}$

$\mathrm{n}=$ number of values in each data set

\section{Results}

\section{Data analysis of macrobenthos community structure}

A total of (21435) individuals, representing 73 species and 42 families were sampled for the eight sites of Kan Maw Island and adjacent areas. There were 39 species of phylum Mollusca, 15 species of Phylum Arthropoda, 14 species of Annelida and each of one species in Phyla Brachiopoda, Echinodermata, Hemichordata, Cnidaria and Nemertea (Table 2). The highest abundance $\left(545 \mathrm{ind} / \mathrm{m}^{2}\right)$ was recorded at Oak Pho Maw station which was characterized by the highest number of Chthamalus depressa (126ind $\left./ \mathrm{m}^{2}\right)$, Amphibalanus reticulates (59ind/ $\left.\mathrm{m}^{2}\right)$, Saccostrea cucullata (59ind $\left./ \mathrm{m}^{2}\right)$, Nassarius stolatus (39ind/ 
$\left.\mathrm{m}^{2}\right)$, and Cerithidea cingulata $\left(31 \mathrm{ind} / \mathrm{m}^{2}\right)$, where loamy sand was found.The second highest abundance was found in Kan Maw Station (400ind $/ \mathrm{m}^{2}$ ) due to high population where was included Chthamalus depressa $\left(114 \mathrm{ind} / \mathrm{m}^{2}\right)$, Sepifer bilocularis $\left(63 \mathrm{ind} / \mathrm{m}^{2}\right)$, Saccostrea cucullata $\left(50 \mathrm{ind} / \mathrm{m}^{2}\right)$, Megabalanus tintinnabulum $\left(23 \mathrm{ind} / \mathrm{m}^{2}\right)$, and Polinices didyma $\left(17 \mathrm{ind} / \mathrm{m}^{2}\right)$, with sediment characteristics that was sandy loam. The lowest abundance $\left(74 \mathrm{ind} / \mathrm{m}^{2}\right)$ was recorded at Chaung Nyi Ko where silt loam sediment was dominant.

\section{Univariate analysis of macrobenthos}

Community structure analysis can be determined the quantitative of macrobenthos occurring in the different areas. These indices were calculated by using the collected data during the study period. Different diversity indices at different stations observed during the study period are presented in Tables 3-4

Table 3 Different diversity indices of macrobenthos at different stations observed during the study period around Kan Maw I, Myanmar

\begin{tabular}{|c|c|c|c|c|c|}
\hline Stations & No of Species & Abundance (ind $/ \mathrm{m}^{2}$ ) & Diversity $\left(H^{\prime}\right)$ & Evenness (E') & Richness (D) \\
\hline Kan Maw & 26 & 340 & 2.18 & 0.67 & 3.05 \\
\hline Taw Kar & 18 & 165 & 1.99 & 0.69 & 2.27 \\
\hline Maw Khaung Tone & 29 & 277 & 2.29 & 0.68 & 3.50 \\
\hline Ka Lein Bae & 21 & 262 & 1.94 & 0.64 & 2.52 \\
\hline Oak Pho Maw & 45 & 545 & 2.77 & 0.72 & 5.19 \\
\hline SandarNge & 18 & 170 & 2.33 & 0.81 & 2.26 \\
\hline KyaukPeit & 16 & 159 & 1.56 & 0.56 & 2.01 \\
\hline Chaung Nyi Ko & 20 & 74 & 2.36 & 0.79 & 2.84 \\
\hline Mean & 24 & 249 & 2.18 & 0.70 & 2.96 \\
\hline
\end{tabular}

Table 4 Chord Distance similarity with respect to macrobenthos at different stations around Kan Maw I, Myanmar

\begin{tabular}{|c|c|c|c|c|c|c|c|c|}
\hline Stations & Kan Maw & Taw Kar & Maw Khaung Tone & Ka Lein Bae & Oak Pho Maw & Sandar Nge & Kyauk Peit & Chaung Nyi Ko \\
\hline $\begin{array}{l}\text { Kan Maw } \\
(\mathrm{KM})\end{array}$ & & 1.04 & 0.55 & 0.60 & 0.67 & 0.70 & 0.63 & 1.30 \\
\hline Taw Kar (TK) & & & 1.23 & 1.28 & 1.21 & 1.32 & 1.40 & 1.34 \\
\hline $\begin{array}{l}\text { Maw Khaung } \\
\text { Tone (MKT) }\end{array}$ & & & & 0.66 & 0.67 & 0.84 & 0.80 & 1.24 \\
\hline $\begin{array}{l}\text { Ka Lein Bae } \\
(\mathrm{KLB})\end{array}$ & & & & & 0.44 & 0.62 & 0.40 & 1.29 \\
\hline $\begin{array}{l}\text { Oak Pho Maw } \\
\text { (OPM) }\end{array}$ & & & & & & 0.72 & 0.69 & 1.19 \\
\hline $\begin{array}{l}\text { Sandar Nge } \\
\text { (SDN) }\end{array}$ & & & & & & & 0.65 & 1.23 \\
\hline $\begin{array}{l}\text { Kyauk Peit } \\
(\mathrm{KP})\end{array}$ & & & & & & & & 1.36 \\
\hline $\begin{array}{l}\text { Chaung Nyi } \\
\text { Ko (CNK) }\end{array}$ & & & & & & & & \\
\hline
\end{tabular}

The Shannon-Weaver diversity index shows the highest and lowest diversity. The evenness index reveals the evenness of distribution of various species in a sample. The Shannon-Weaver index is maximum when all the species in a sample are equally abundant, decrease towards zero as the relative abundance of species diverse away from the evenness. The maximum values of macrobenthic fauna and diversity indices: 45 species diversity, 5867 individuals, $2.77\left(H^{\prime}\right)$ and
5.19(D) was found in Oak Pho Maw station. In addition, the highest evenness(0.81) was found in Kyauk Peit. The minimum values: 16 species diversity, $1.56\left(H^{\prime}\right), 0.56\left(E^{\prime}\right)$ and $2.01(D)$ was as found in Kyauk Peit. But the lowest abundance (796 individuals) was found in Chaung Nyi Ko at different stations during the study period. These results are summarized in Table 3 and Figures 1-3. 

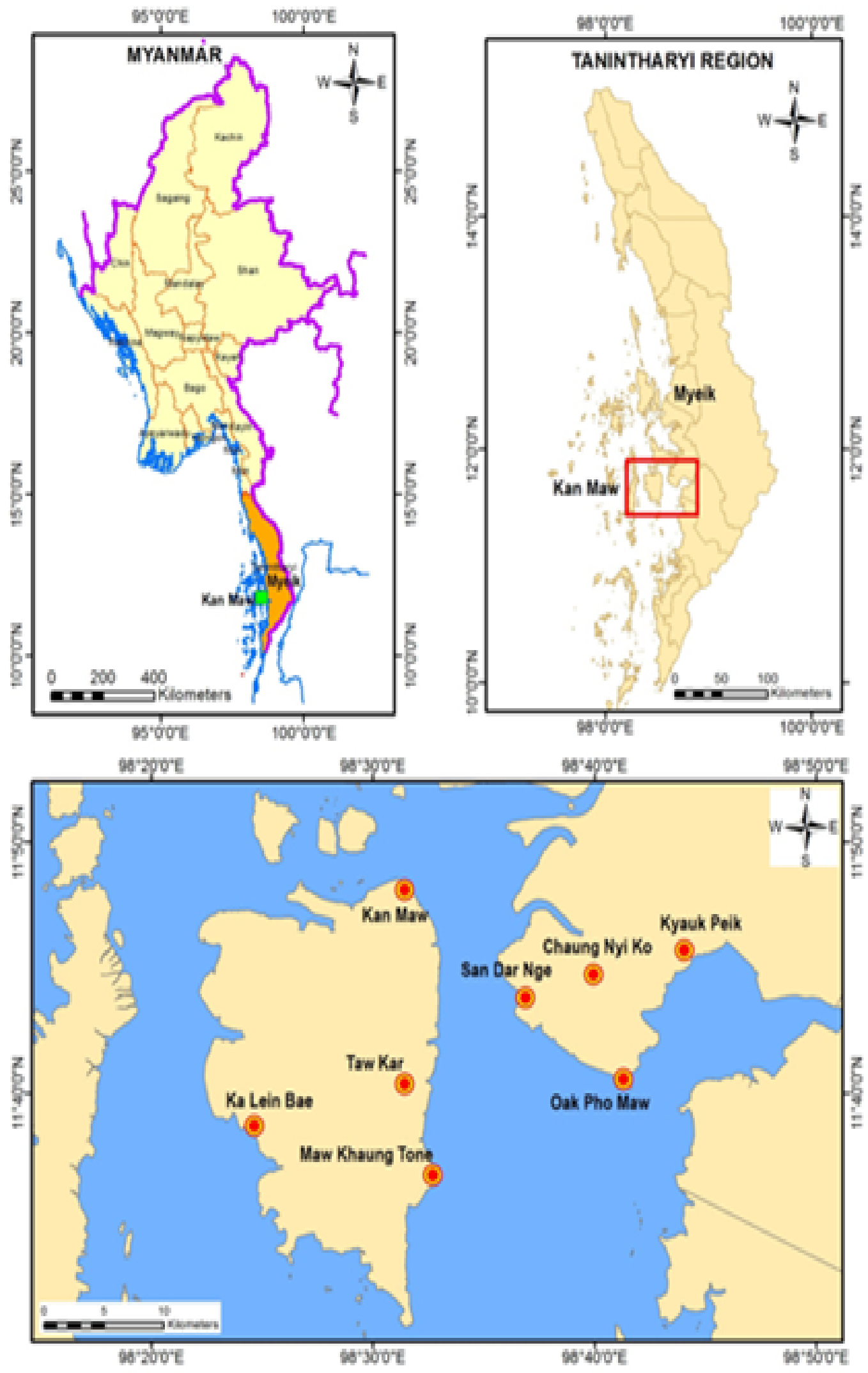

Figure I Map showing the study areas of intertidal macrobenthos in Kan Maw Island and adjacent areas, Myanmar. 


\section{Abundance - (Diversity) $\mathrm{H}^{\prime}-$ (Evenness) $\mathrm{E}^{\prime}-$ No of Species}

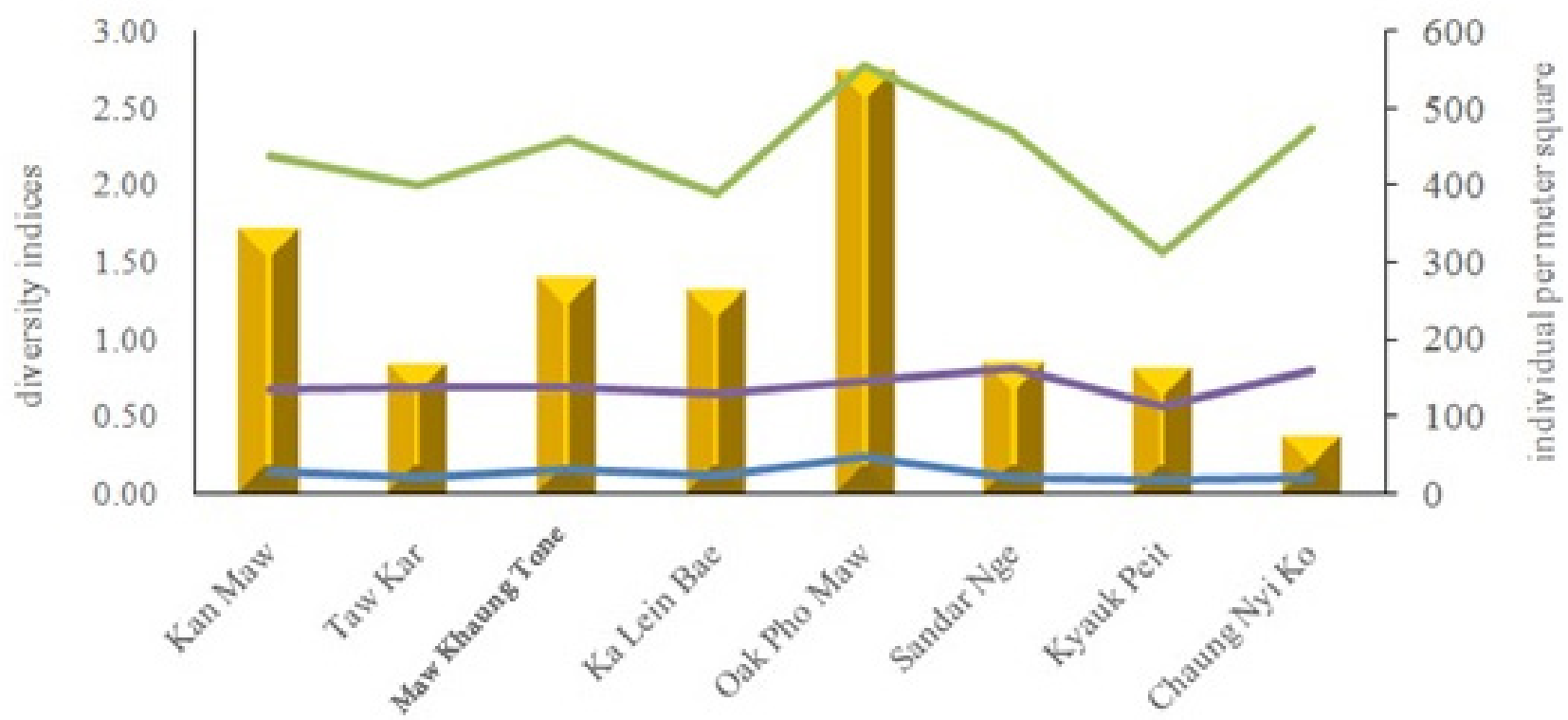

Figure 2 Variation of diversity indices of macrobenthos at different stations during the study period around Kan Maw I, Myanmar.

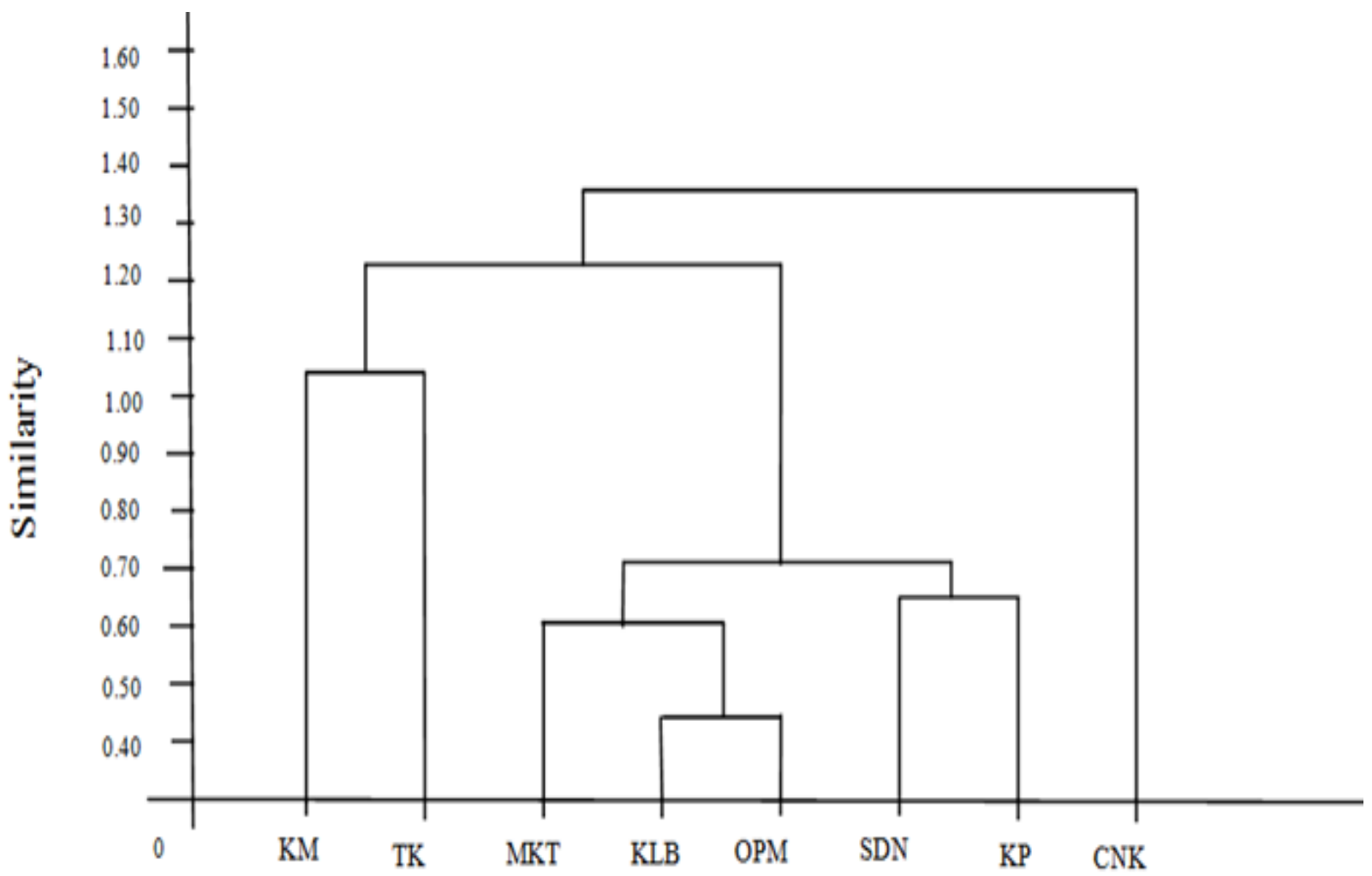

Figure 3 Station-wide similarities of macrobenthic communities in Kan Maw Island and adjacent areas during 20I7-20I9. 


\section{Multivariate analysis of macrobenthos}

Multivariate methods were used to compare the community that related to the identified species and abundance. From this method, similarities index was calculated using Chord distance (CRD) index formula. The range of this similarities index was from 0.40 in $\mathrm{Ka}$ Lein Bae-Kyauk Peit as the minimum similarities to 1.40 in Taw KarKyauk Peit as the maximum.

\section{Correlation of macrobenthic communities (Diversity indices) with environmental parameters}

Pearson correlation test results of macrobenthic communities with environmental parameters and sediment characteristics were shown in Table 5. Soil $\mathrm{pH}$ did not have a significant impact on mean abundance, Shannon-Weiner index and Simpson index. Salinity, temperature and sand had a significant negative effect on abundance and diversity indices. Sediment characteristics varied significantly depending on different stations. Silt had a negative correlation that effect on richness
(-0.12) and a positive correlation with mean abundance, species diversity $\left(H^{\prime}\right)$ and evenness $\left(E^{\prime}\right)$. Clay was highly correlated with mean abundance (0.05), species diversity $(0.07)$ and evenness $(0.10)$ as a positive correlation and had an insufficient effect on richness $(-0.26)$ as a negative correlation.

\section{Correlation of macrobenthic fauna (Phyla) with environmental parameters}

The correlation of each Phylum with environmental parameters and sediment characteristics (water temperature, water salinity, soil $\mathrm{pH}$, sand, silt, clay) showed clear differences and degree of association. Mollusca, Arthropoda and Annelida groups showed a weak negative correlation with $\mathrm{pH}$. However, $\mathrm{pH}$ had positive correlation with Brachiopoda, Echinodermata, Hemichordata, Cnidaria and Nemertea, with the result value of +0.29 and on Cnidaria with the value +0.23 . Moreover, Brachiopoda, Echinodermata, Hemichordata, Cnidaria and Nemertea groups had a positive correlation with salinity and temperature but other groups had a negative correlation (Table 6).

Table 5 Correlation of macrobenthos (diversity indices) with environmental parameters around Kan Maw I, Myanmar

\begin{tabular}{lllllll}
\hline Correlations & $\mathbf{p H}$ & Salinity & Temperature & Sand & Silt & Clay \\
\hline Mean abundance & -0.80 & -0.37 & -0.83 & -0.86 & 0.4 & 0.05 \\
(Diversity) $H^{\prime}$ & -0.01 & -0.46 & -0.71 & -0.55 & 0.02 & 0.07 \\
(Evenness) E' & 0.23 & -0.18 & -0.43 & -0.43 & 0 & 0.10 \\
(Richness) D & -0.63 & -0.61 & -0.01 & -0.76 & -0.12 & -0.26 \\
\hline
\end{tabular}

+ =Positive correlation, - =Negative correlation

Table 6 Correlation of macrobenthicfauna (Phyla) with environmental parameters around Kan Maw I, Myanmar

\begin{tabular}{|c|c|c|c|c|c|c|}
\hline Phyla & $\mathrm{pH}$ & Salinity & Temperature & Sand & Silt & Clay \\
\hline Mollusca & -0.87 & -0.8 & -0.79 & -0.62 & 0.21 & -0.17 \\
\hline Arthropoda & -0.56 & -0.56 & -0.48 & -0.83 & 0.48 & -0.02 \\
\hline Brachiopoda & 0.29 & 0.05 & 0.08 & -0.18 & -0.13 & -0.18 \\
\hline Echinodermata & 0.29 & 0.10 & 0.15 & -0.06 & -0.25 & -0.15 \\
\hline Annelida & -0.39 & -0.73 & -0.48 & -0.26 & 0.55 & 0.86 \\
\hline Hemichordata & 0.29 & 0.17 & 0.23 & -0.06 & -0.18 & -0.25 \\
\hline Cnidaria & 0.23 & 0.27 & 0.29 & 0.07 & 0.29 & -0.07 \\
\hline Nemertea & 0.29 & 0.05 & 0.08 & -0.18 & -0.13 & -0.18 \\
\hline
\end{tabular}

$+=$ Positive correlation, - =Negative correlation

Sand was positively correlated with Cnidaria abundance $(+0.07)$ and negatively correlated with Annelida (-0.26), Arthropoda (-0.83) and Mollusca (-0.62), Nemertea and Brachiopoda (-0.18), Echinodermata and Hemichordata (-0.06) (Table 5); silt was positively correlated with Mollusca (+0.21), Arthropoda (+0.48), Annelida $(+0.55)$ and Cnidaria $(+0.29)$ abundances, but there was so significant correlation with Brachiopoda (-0.13), Echinodermata (-0.25), Hemichordata (-0.18) or Nemertea $(-0.13)$, which were weakly negatively correlation. Moreover, clay showed a strong positive correlation $(+0.86)$ with Annelida, and weaker negative correlations with Cnidaria (-0.07), Arthropoda (-0.02), Echinodermata (-0.15), Mollusca (-0.17), Brachiopoda and Nemertea $(-0.18)$, and Hemichordata $(-0.25)$ in macrobenthic groups.

\section{Discussion}

The community structure of macrobenthos was analyzed in the intertidal zone of Kan Maw Island and adjacent areas during May 2017- April 2019. A total of 73 species of macrobenthos belonging to eight phyla, 12 classes, 21 orders, 42 families and 52 genera were identified. During the study period, Molluscs had the highest diversity (39 species), followed by Arthropods (15 species) and Annelida (14 species). Only one species was found from each Phylum of Brachiopoda, Cnidaria, Echinodermata, Nemertea and Hemichordata. In addition, Mollusca was common in the intertidal zone of all stations (except Kyauk Peit) comparing with other Phyla. Among the stations, Oak Pho Maw (45 species) was the most diverse site followed by Maw Khaung Tone (29 species) and Kan Maw (26 species). 
The mollusks were the most diverse and abundant group of animals that formed $39.37 \%$ of total fauna assemblage in Sonmiani Bay, Balochistan. ${ }^{26}$ Moreover, the diversity of marine mollusks was distributed in South East coast of India (63 species), ${ }^{27}$ inner gulf of Thailand (18 species), ${ }^{28}$ Malaysia (30 species) ${ }^{29}$ and Philippine (57 species).$^{30}$ In the present observation, the most common macrobenthos were the molluscs Chthamalus depressus, followed by Saccostrea cucullata, Sepifer bilocularis, Amphibalanus reticulatus, Cerithidea cingulata, Megabalanus tintinnabulum, Thais mutabilis, Polinices didyma, Nassarius stolatus and Littorina scabra. This dominant groupwas divided into two groups: sessile and motile species for all stations. sessile species were the most common, as one would expect for soft sediments. Statistical analysis showed that diversity, density and sediment quality did not differ significantly between mangrove and mud flat areas but dominant species were different. ${ }^{31}$

According to Ahmad, ${ }^{32}$ four higher taxa were recorded at the sandy shore including Polychaeta, Crustacea, Mollusca and Echinodermata with the highest abundance by Phylum Mollusca: $89.4 \%$. In the fact of present observation, mollusk was the highest abundance and constituted (53.0\%), Arthropod (44.6\%), Annelida (1.7\%), Brachiopoda (0.2\%) and Cnidaria $(0.5 \%)$, were found during two years. The mollusks were the most diverse and abundant group of animals. This compares to other studies, such as one that found Mollusca comprised nearly $40 \%$ of the total fauna assemblage in Sonmiani Bay, Balochistan. ${ }^{33}$ In the present observations, diversity and abundance of mollusk was common group among the macrobenthic fauna of all stations.

In 2010, Datta et al. ${ }^{34}$ described that a scale of pollution in terms of Shannon's species diversity was 3.0-4.5 slight, 2.0-3.0 light and 1.0-2.0 moderate and 0.1-1 heavy pollution. The range of Shannon's species diversity was 1.56-2.36. In general, diversity indices recorded werehigh $>3$ at all stations after an oil spill..$^{30}$ In the present study, the values of diversity index were not found $>3$ at all stations. Using the above scale, we could infer that minor pollution was found in Kan Maw (2.18), Maw Khaung Tone (2.29), Oak Pho Maw (2.77), Sandar Nge (2.33) and Chaung Nyi Ko (2.36). And three stations had moderate pollution, Taw Kar (1.99), Ka Lein Bae (1.94) and Kyauk Peit (1.56). It is considered that these stations were impacted from light to moderate pollution condition. These low value stations had many anthropogenic impacts and unfavorable environmental condition such as domestic waste, uncontrolled utilization of natural resources, increased sedimentation and losing habitats. So, these stations are needed to conserve to be the healthy environmental condition.

The stability of a community can be illustrated by a high value of the evenness coefficient $\left(E^{\prime}\right)$, which indicates that the community is evenly distributed. A smaller the $E$ ' value indicates a patchy distibution. ${ }^{35}$ From the present results, the stable condition was found in Sandar Nge station (0.81) as the highest value and unstable condition was found in Kyauk Peit station (0.56) as the lowest value. The local people from Kyauk Peit discharged the domestic wastes and filled the soft substratum by putting the logs and the powders of wood and the external layer of trunks. Moreover, overexploitation of mangroves was increased for their livelihood.

Generally, in a healthy environment Margalef richness index is higher in the range of 2.5-3.5. ${ }^{36}$ Moreover, ${ }^{34}$ recorded that Margalef richness index ranged from 2.93-5.71 from different sites indicating the rich diversity of these shores. In the present observation, the average range of richness index was from 2.01 to 5.09 at different stations that indicated a healthy environment and rich diversity in most stations except Kyauk Peit (2.01), Sandar Nge (2.26) and Taw Kar (2.27)

Salinity has been reported to control the distribution and the reproduction of certain macro-benthic fauna. ${ }^{37}$ Temperature is also an important ecological factor, which influences the distribution of benthic organisms. ${ }^{38}$ In the present observation, the salinity was ranged from 15\% (in July) to 35\% (in January and March). The water temperature was ranged from $20^{\circ} \mathrm{C}$ to $34^{\circ} \mathrm{C}$. The sediment $\mathrm{pH}$ ranged from 5.7 to 6.4. The change of $\mathrm{pH}$ was very small in all stations but salinity and temperature widely fluctuated. Some stations are faced with highly fluctuating salinity due to their proximity to tidal creeks where the fresh water flows into it. It is assumed that the different environmental parameters of different stations may change diversity and abundance of macrobenthos. Meteorological parameters and anthropogenic impacts including increased urbanization can also impact biodiversity.

The method of Spearman's Rank correlation coefficient was chosen to assess the rank of variation, correlation and differences of relationships between two variables. Species richness was positively correlated with salinity irrespective of the group considered in intertidal organisms in Uruguay. ${ }^{39}$ According to our present study, correlation between the mean value of salinity and species richness was also not significant and weakly negative. Similarities from the output result, the effect of salinity showed negative correlation toward zero that was -0.37 in mean abundance, -0.46 in diversity $\left(H^{\prime}\right)$ and -0.18 in evenness $\left(E^{\prime}\right)$ and -0.61 in richness $(D)$.

Water salinity, temperature and soil $\mathrm{pH}$ were positively correlated with most macrobenthic groups in the present observations. Mollusks were positively correlated with silt while negatively correlated with other environmental factors. That point was not agreed with the result of. ${ }^{40}$ It is assumed that mobile mollusks may change their behavior to avoid unfavorable conditions. Abundance and species richness of mollusks were only weakly correlated with temperature $(\mathrm{R}=0.44$ and 0.47$) .{ }^{41}$ Temperature was negatively correlated with both mean abundance and richness in the present observations. All physio-chemical parameters are important factors in macrobenthos distribution and abundance. Ecologically, benthic diversity is controlled by a combination of factors such as temperature, salinity, dissolved oxygen, sand and organic matter, and no single factor could be considered as an ecological master factor. ${ }^{42}$ So, correlation between the biotic and abiotic factors is important from ecological point of view.

The information gained from monitoring benthic macro invertebrate communities has been used widely to measure the status and trends in the ecological condition of estuaries. Estimation of benthic abundance is necessary for the assessment of demersal fishery resources as benthos forms an important source of food for demersal fishes. Macrobenthos might be considered as good indicators to assess the environmental pollution condition. The macrobenthos and birds to be both involved in a complex food web ${ }^{43}$ therefore the macrobenthos contribution to energy flow and especially to the diet of birds should be considered in resource assessments. ${ }^{44}$ The effect of birds on the macrobenthos communities should be investigated in these stations.

The information gained from monitoring benthic macron invertebrate communities has been used widely to measure the status and trends in the ecological condition of estuaries. The top priority therefore should be given for preservation, sustainable utilization, and 
restoration of ecology through conservation of coastal habitats and their biodiversity. In developing countries, information on tropical intertidal communities was needed to provide background information for coastal zone management programs by. ${ }^{45}$

\section{Conclusion}

The intertidal biota of Kan Maw Island and adjacent areas has been investigated by community structure of macrobenthos. A total of 21435 individuals under eight phyla of macrobenthos were observed, of which, the phylum Mollusca represents the most abundant organisms (53.0\%), followed by Arthropoda (44.6\%) and Annelida $(1.7 \%)$.To determine the diversity indices, the formula of Margalef's richness $(D)$, Shannon-Weaver's diversity index $\left(H^{\prime}\right)$ and evenness index $\left(E^{\prime}\right)$ were utilized that indicated different level of ecological state of the present study areas in different months. In all stations, KyaukPeit showed the more polluted according to their output research. Based on biotic-abiotic correlation analyzed, the values of salinity, temperature and soil $\mathrm{pH}$ are the abiotic component that has the most influence in the most macrobenthic abundance during the study period. In addition, macrobenthic groups (except Mollusca and Arthropoda, Annelida) had positive correlation with $\mathrm{pH}$, salinity, temperature. And the abundance of macrobenthos also has positive correlation with clay and silt. Oak Pho Maw was the highest abundance station $\left(545 \mathrm{ind} / \mathrm{m}^{2}\right)$ and Chaung Nyi Ko, the lowest abundance (74 $\mathrm{ind} / \mathrm{m}^{2}$ ) among the eight stations. However, macrobenthic fauna are being decreased in the present study areas; this may be because of overexploitation and habitat destruction. This result can be considered as a preliminary survey and supported as baseline knowledge of macrobenthic community for future research, resource management and sustainable development.

\section{Acknowledgments}

I am also indebted to my supervisor Dr. San Tha Tun, Professor and Head of Department of Marine Science, Mawlamyine University for his valuable suggestion and encouragement to make this research. I thank Sue Murray-Jones, Flinders University of SA, Australia for her invaluable guidance of the manuscript. And special thanks to Daw Tin Cho and her family who live in Oak Pho Maw village and other local people for their giving needful help to collect the samples during my research work.

\section{Conflicts of interest}

The author declares that there is no conflicts of interest.

\section{Funding}

None.

\section{References}

1. Tagliapietra D, Sigovini M. Benthic fauna: collection and identification of macrobenthic invertebrates. Terrre et Environment. 2010;88:263-261.

2. Macdonald T, Burd B, Roodselaar AV. Size structure of marine softbottom macrobenthic communities across natural habitat ingredients: implications for productivity and ecosystem function. Plos ONE. 2012;7(7)

3. Tarwotjo MBU, Rahadian R, Had M. Community structure of macrozoobenthos as bioindicator of pepe river quality. IOP Conf. Series. Journal of Physics: Conf. Series.2018;1025:1-7.
4. Darif NAM, Samad NSA, Salleh S, et al. The abundance and spatial distribution of soft sediment communities in TanjungBungah, Malaysia; A preliminary study. Tropical Life Sciences Research. 2016;27:71-77.

5. Basu A, Sengupta S, Dutta S, et al. Studies on macrobenthic organisms in relation to water parameters at East Calcutta Wetlands. Journal of Environmental Biology. 2013;34:733-737.

6. Saad AEA, Khalil MT, Fishar MR. Biodiversity of meiobenthic invertebrates in lake Bardawilll, Egypt. J Aquat Biol. \& Fish. 2012;16(4):139-149.

7. Anandan K, Varshney PK, Jaiswar AK, et al. Macrobenthos of intertida zone of Versova along the coast of Mumbai. Journal of the Indian Fisheries Asso. 2003;9-17.

8. Tweedie MWF. On the crabs of the family Ocypodidae in the collection of the Raffles Museum. Bulletin of the Raffles Museum, Singapore Straits Settlements. 1937;140-170.

9. Morris PA. A field guide to Pacific coast shells. Houghton Mifflin company, Boston. 1952; p. 296.

10. Day JH. A Monograph on the Polychaeta of Southern Africa, Part I \& II, Errantia and Sedentaria. Treasure of the British Museum (National History) London,.1967; p.878.

11. Tantanasiriwong R. An illustrated checklist of marine shelled gastropods from Phuket Island, adjacent mainland and offshore Island, western Peninsular Thailand. Bull Mar Biol Cent. Phuket. Thailand. 1978; 21:122

12. Soe Thu. Taxonomy and distribution of Burmese marine gastropods. Unpublished M.Sc. Thesis. Department of Zoology, Arts and Science University, Rangoon. 1980.

13. Narasimham KA. Taxonomy of the blood clams Anadara (Tegiliarca) granosa (Linnaeus, 1758) and $A$. (T.) rhombea (Born, 1780). J mar boil Ass India.1988;30 (1\&2):200-205.

14. Rizzo M, Schembri PJ. The Thoracican barnacles (Cirripedia: Thoracica) of the Maltese Island and surrounding waters (central Mediterranean). The central Mediterranean Naturalist. 1997;2 (4):108-174.

15. Poutiers JM. Gastropods of the Western Central Pacific. FAO, Rome 1998; p. 686

16. Ng PKL. Crabs of the Western Central Pacific. FAO, Rome. 1998;10461155 .

17. Subba Rao NV, Dey A. Catalogue of Marine Mollucs of Andaman and Nicobar Islands. Ree zool Surv India, Occ, 2000; 187: i-X, 1-323 p.

18. Dance S. Shells. Published in association with America's preeminent authority, the Smithsonian Institution, 2002; $256 \mathrm{pp}$.

19. Subba Rao NV. Indian Seashells (Part-I): Polyplacophora and Gastropoda. Rec. zool. Surv, India. 2003;Occ.Paper No. 192: i-x, 1-416.

20. Ahyong ST, Chan TY, Liao YC. A catalog of the mantis shrimps (Stomatopoda) of Taiwan. National Taiwan Ocean University, Keelung. 2008;1-190.

21. Al-Omari NHA. A guide to Polychaetes (Annelida) in Qatar marine sediments. Environmental Studies Center - Qatar University. 2011;176 p.

22. Wilhm JL, Dorris, TC. Species diversity of benthic macroinvertebrates in a stream receiving domestic and oil refinery effluents. Am. Midland Nat. 1966;76(2):427-449.

23. Pielou EC. The measurement of diversity in different types biological collection. $J$ Theor Biol. 1966;13:131-144.

24. Margalef R. Perspectives in Ecological Theory. University of Chicago Press, Chicago, 1968; IL: 111. 
25. Ludwig JA, Reynolds JF. Statistical Ecology: Primer on methods and computing, John Wiley \& Sons, A Wiley International Publication, New York., 1990; 330 p.

26. Gondal MA, Saher NU, Qureshi NA. Diversity and biomass distribution of intertidal fauna in Sonmiania Bay (Mianihor), Balochistan (Phakistan). EgyptAcad JBiolog Sci.2012;4(1):219-234.

27. Paul P, Panigrahi AK, Tripathy B. A study of marine molluses with respect to their diversity, relative abundance and species richness in North-East coat of India. Indian Journal of Applied Research. 201;4(12):538-541.

28. Premcharoen S, Witirawat S, Tharapoom P. Molluscan fauna in Bang Taboon mangrove estuary, inner gulf of Thailand: Implications for conservation and sustainable use of coastal resources. MATEC web of conferences. 2016; 60:1-5.

29. Halim SSA, Shuib S, Talib A, et al. 2019. Species composition, richness and distribution of molluscs from intertidal areas at Penang Island, Malaysia. Songklanakarin J. Sc. Technol. 2019;41(1):165-173.

30. Masagca, JT, Mendoza AV, Tribiana ET. The status of mollusk diversity and physical setting of the mangrove zones in Catanduanes Island, Luzon, Philippines. BIOTROPIA. 2010;17 (2):62-76.

31. Srisunont C, Thongsanit N, Suttiwichai J, et al. Diversity index of macrobenthos and environmental factors in mangrove and mudflat areas at Klong Khone, Samut Songkhram Province. Proceedings of the $3^{\text {rd }}$ National meeteing on biodiversity management in Thailand. 2016;3:239245 .

32. Ahmad, O, Fang, TP, Yahna, K. Distribution of intertidal organisms in the shores of TelukAling, Pulau Pinna, Malaysia. Publ Seto Mar Biol Lab.2011;41:51-61.

33. Gondal MA, Saher NU, Qureshi NA. Diversity and biomass distribution of intertidal fauna in Sonmiania Bay (Mianihor), Balochistan (Phakistan). Egypt Acad J Biolog Sci. 2012;4 (1):219-234.

34. Datta SN, Chakraborty SK, Faiswar AK et al. A comparative study on intertidal faunal biodiversity of selected beaches of Mumbai coast. Journal of Environmental Biology. 2010;31(6):981-986.
35. Joydas TV, Qurban MA, Borja A, et al. Macrobenthic community structure in the Northwestern Arabian Gulf, Twelve Years after the 1991 Oil spill. Front Mar Sci. 2017; 4:248.

36. Khan SA, Murugesan P. Polychaete diversity in Indian estuaries. Indian Journal of marine sciences. 2005;34(1):114-119.

37. Lamptey E, Armah AK. Factors affecting macrobenthic fauna in a tropical Hypersaline coastalagoonin Ghana, West Africa. Estuaries and Coats. 2008;31:1006-1019.

38. Varadharajanm D, Soundarapandian P, Gunalan B, et al. Seasonal abundance of macrobenthic composition and diversity along the south east coast of India. European Journal ofApplied Sciences. 2010;2(1):1-5.

39. Gimenez L, Borthagaray AI, Rodriguex M, et al. Rocky intertidal macrobenthic communities across a large-scale estuarine gradient. Sci. MAR. 2010;74(1):1-14.

40. Jayaraj KA, Jayalakshmi KV, Saraladevi K. Influence of environmental properties on macrobenthos in the northwest Indian shelf. National institute of oceanography, Regional Center, Kochi-682018, India. 2007.

41. Armenteros M, Saladrigas D, Gonzalez-Casuso L, et al. The role of habitat selection on the diversity of macrobenthic communities in three gulfs of the Cuton Archipelago. Bull Mar Sci. 2018, 94 (2):249-268.

42. Pathak MR, Abido MS. The role of biotechnology in the conservation of biodiversity. Journal of Experimental Biology and Agricultural Sciences. 2014;2 (4):352-363.

43. Valiela I, Ruteckim D, Fox S. Salt marshes: Biological controls of food webs in a diminishing environment. Journal of Experimental Marine Biology and Ecology. 2004;300 (1):131-159.

44. Ouisse V, Riera P, Migne A, et al. Freshwater seepages and ephemeral macroalge proliferation in an intertidal bay: I Effect on benthic community structure and food web. Estuarine, Coastal and Shelf Science. 2011;91:272-281.

45. Vargas JA. Community structure of macrobenthos and the results of macropredator exclusion on a tropical intertidal mud flat. Rev Biol Trop. 1988;36(2A):287-308. 